\title{
Study on creation of water sources supplying the inner river system in Hanoi city with continuous flow for cleaning the aquatic environment
}

\author{
Hue Huu Nguyen $^{1}$ and Thanh Huu Nguyen ${ }^{1, *}$ \\ ${ }^{1}$ Thuyloi University, 175 Tay Son Street, Dong Da District, Hanoi, Vietnam
}

\begin{abstract}
Vietnam is currently facing major challenges from ongoing water pollution in urban rivers. In the city of Hanoi, the amount of domestic waste water, industrial waste water, and waste water from unprocessed trade villages are discharged directly into the rivers, which are the main causes of water pollution. The biggest problem now is how to deal with the current state of water pollution in the inner rivers of Hanoi with the focus on Day, Nhue, and To Lich river systems. This article presents the study to determine Route Works for a gravity based water supply system that provides continuous flows to these rivers. Then, the one-dimensional hydrodynamic model (HEC-RAS V4.1) is used as a basis for assessing the effectiveness of the solution. Through the results of the study, it was once again confirmed that the construction of a gravity based water supply system is feasible, both to improve the aquatic environment of the rivers and to ensure the supply of irrigation water for production.
\end{abstract}

\section{Introduction}

Although Hanoi is the capital of Viet Nam, the pollution of water in inner rivers, such as Day River, Nhue River, and To Lich River is still increasing dramatically and becoming more difficult to control. In the dry season, the natural flow of these rivers is almost non-existent, so many people have used polluted water, the source of which is wastewater, to irrigate rice, vegetables, and crops. These activities have seriously affected the quality of agricultural products, food, and people's health. The strong evidence for this is that the rate of acute and chronic diseases associated with water pollution, such as dermatitis, gastroenteritis, diarrhea, and increased risk of cancer, which have caused many annoyances in the heart of people living nearby the area.

The city's government has long been determined to invest in research, calling for international support with the desire to find solutions to this problem. In 2009, the Department of Natural Resources and Environment of Hanoi has submitted a plan to implement the project "Urgent solutions to solve water environment pollution" with a total investment of around 1,329 billionVND, which includes plans to take water from the Red River through Lien Mac water intake to To Lich River to deal with pollution. After that, 09/2015, the Hanoi delegation led by the Chairman of the Hanoi People's Committee visited

* Corresponding author: nguyenhuuhue@tlu.edu.vn 
and worked in Amsterdam, where the mayor of Amsterdam agreed to cooperate and support the city in improving water environment. Then, the Institute for Rural AssistanceResearch Development (IRARD) proposed the Hanoi People's Committeefor the pilot use ofchemicals to clean water in To Lich River. According to the proposed solution, after spraying this chemical liquid, the stench will decrease immediately, but the water will take 1-2 days get back to the color of clean water, and that lasts one month. Then, a weir will be built to rise water levelbefore flowing into the river to create flow.

With the considerable efforts of people and local authority, the pollution of the rivers is still gettingmore and more serious, and the rivers are now functioning as waste water systems.In response to the above urgent needs, the authors have conducted a study on determiningRoute Works for a gravity based water supply systemto create water sources for revitalizing Hanoi's inner rivers. At the same time, the proposed solution also provides irrigation water for agricultural production.

\section{Literature review}

- In the early 90s of the 20th century, To Lich River started to have pollution phenomenon. Local authorities have urged scientists, consulting agencies, domestic and foreign sponsors to find solutions to reduce pollution in urban rivers.

- Since 1997, Hanoi Water Supply and Drainage Company has investigated, surveyed and formulated plans to treat water pollution in To Lich river system. Since 2003, the To Lich River has started to be dredged and the embankments along the banks are reinforcedunder the Hanoi drainage project (phase 1), so the quality of river water has also been partially improved.

- From 1999 to 2003, the Institute of Natural Products Chemistry (INPC) studied the water quality of the Nhue and To Lich rivers by conducting monthly observations on DO, độ đục, NO3-, PO42-, NH4-N, P-T...

- Every year, the Hanoi Department of Natural Resources and Environment has carried out monitoring of To Lich River in dry season and rainy season. Accordingly, the quality of river water is increasingly seriously polluted.

- In 2005, the Institute of Geography carried out the project "Building scientific basis for solution of adding surface water forHanoi's river to reduce environmental pollution". The study has given some new solutions for waste water collection and treatment ... However, the water source for creating new flows in these rivers has not been completely solved.

- In 2007, in the final report of the comprehensive urban development programme in Hanoi Capital City of the Socialist Republic of Vietnam (HAIDEP), the Japan International Cooperation Agency (JICA) proposed a solution of getting water from Red River into West Lake with discharge of $7 \mathrm{~m} 3 / \mathrm{s}$, then bring it to the main lakes as well as To Lich and Kim Nguu rivers, or pump water directly from the Red River into the rivers in the city. However, so far no specific action has been taken.

- In 2008: the Institute for Rural Assistance Research Development (IRARD) has proposed the Hanoi People's Committee for the pilot use ofchemicalsthat to be researched successfulnamed HQ1, HQ2, HQ3 to clean water of To Lich River. When implemented in practice, because of high cost and unpredictable effects, these products have not been widely deployed.

- Another solution is to use active ingredients LTH-100 by Green Technology Joint Stock Company deployed research for many years. The use of chemicals is often suitable for static waters, due to the characteristics of the To Lich as continuous replenishment of wastewater along the river banks, so the use of chemicals is difficult to be feasible. 
- The technology of the dredge, compressed air technology of the Research Institute of Mechanical Engineering was put to trial in To Lich River, but this technology has just stopped at the research level, while the scaling and deployment on the big scale is still limited.

- In 2012: Binh Minh Construction and Tourism Corporation has carried out research project"Water supply system combining electricity generation, transportation and improving the landscape of Ha Noi capital". The scheme consists of three components: 1) Water supply for Hanoi capital from Hoa Binh reservoir through the tunnel system is used to generate electricity with capacity of about $100 \mathrm{MW}$, before supplying clean water to downstream; 2) Construction of weirs on Red river combined with traffic bridges; 3) Upgrading the part of Day river which runs through the city of Hanoi. With the main objective are: providing clean water source for sustainable operation, low cost for living, industrial and other water use for Hanoi capital and surrounding areas. Due to the total massive investment of 10 billion dollars, the project is unfeasible.

The above review shows that although scientists as well as domestic and foreign consultants are working to find and propose solutions to reduce pollution of rivers, the reality is that the solutions presented are not really effective.

\section{Materials and methods}

\subsection{Overview of the study area}

The study the area, let's focus on the three most important rivers of Hanoi: Day River, Nhue River and To Lich River. These rivers have created the mythical beauty of the water city of Hanoi, not only to enrich human life, to balance the ecology for sustainable development but also to attach to the spiritual culture towards the roots. 


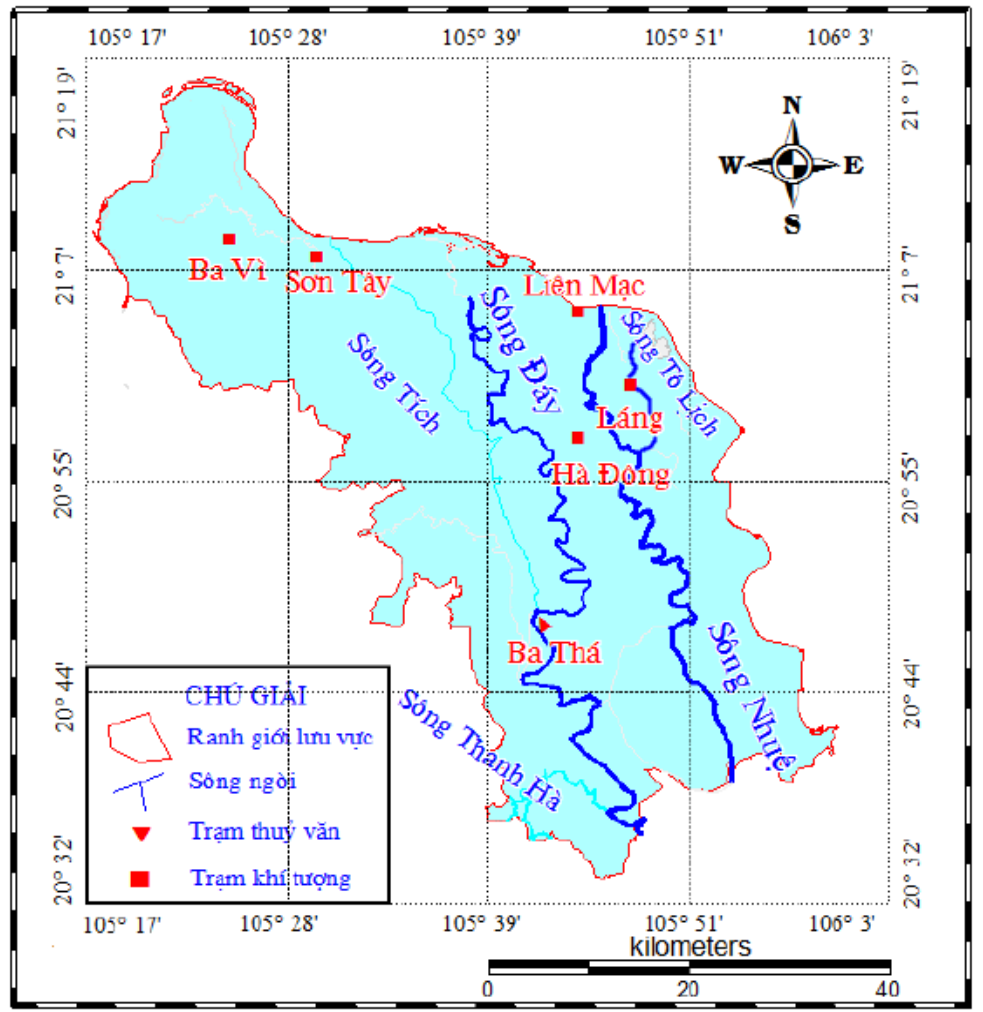

Fig. 1. Map of Nhue - Day - To Lich river basin in Hanoi.

+ Day River: a length of about $247 \mathrm{~km}$ from the source of Cam Dinh water intake to the Day mouth before flowing into the East Sea. In the area of Hanoi, the river is about $71 \mathrm{~km}$ long (from Cam Dinh sluice to Ba Tha hydrological station). Previously, the Day River was a tributary of the Red River, but by 1937, after Day dam was completed, the Day River was flooded only from the Red River in 1940, 1945, 1969, and 1971. Today, the upper part of Day River (the part runs through the city of Hanoi) is considered asa dead river and it becomes the water drainage.

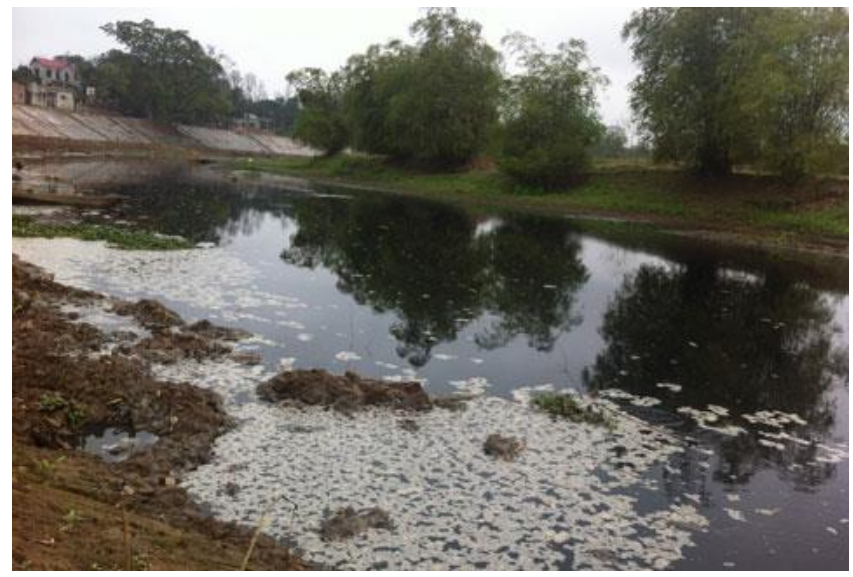

Fig. 2. Status of polluted Day River water (10/2016). 
+ Nhue River: 74 km in length from Lien Mac water intake to Phu Ly sluice in Ha Nam province (confluence with Day river). In the area of Hanoi, the river has a length of about $61.5 \mathrm{~km}$ with an average width of $30 \div 50 \mathrm{~m}$. Nhue River water is polluted by receiving waste water from Hanoi. There have been many environmental incidents on the Nhue River such as mass dead fish due to discharge of sewage in the dry season.

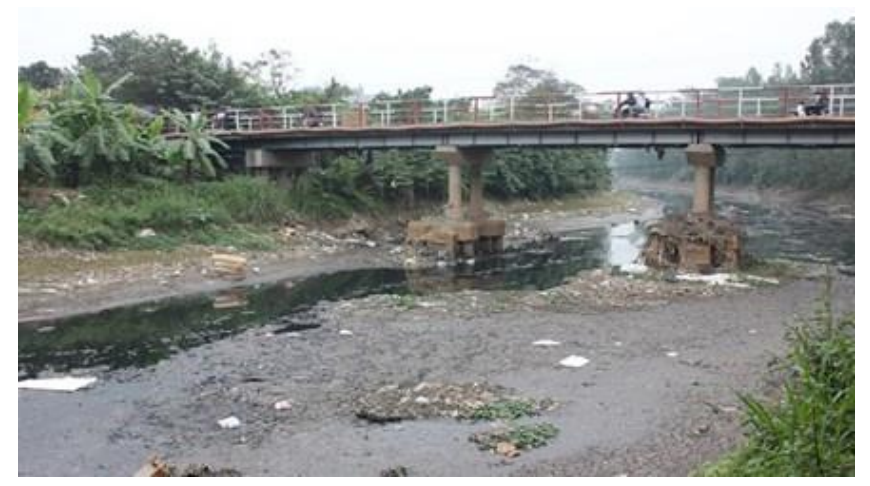

Fig. 3. Status of Nhue River water pollution (10/2016).

+ To Lich River: a length of $14.6 \mathrm{~km}$ starting from Hoang Quoc Viet street, pouring into the Nhue River through Thanh Liet sluice, with an average width of $40 \div 50 \mathrm{~m}$. The end of the To Lich River takes up all of the city sewage. The results of water observation in To Lich river show that river water turns black, has scum, sediment and stench.

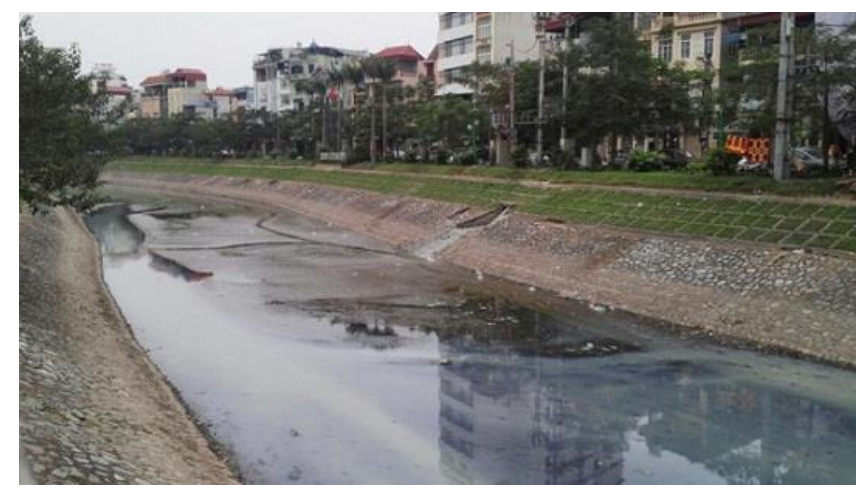

Fig. 4. Status of To Lich River water pollution (08/2016).

\subsection{Documentation for research}

To provide Route Works for a gravity based water supply systemcreating flows for the Day, Nhue, and To Lich River as the most effective way, the study has concentrated on researching and exploiting related documents including:

+ Master plan for socio-economic development of Hanoi city to 2020, orientation to 2030: The proposal ofa gravity water supply system creating flows to revitalize urban rivers must be consistent withthe general planning of the city. In addition, the proposed work must also contribute to the development and improvement of the planning.

+ Maps of Hanoi irrigation master plan, city spatial planning maps... The maps will be the basis for delineating the gravity water supply system.

+ Implementingtopographic and geological survey of project areas. In particular, the topographic measurement helps to determine the appropriate slope of route to ensure that 
water can flow efficiently. Geological measurements will help identify areas with stable geological foundations for the construction of works.

+ Documents on water levels, flows, and water quality of rivers within the study area: This is the basis for determining the source of water that can be collected and supplied to urban rivers. As well as evaluating the stability of the water providing sources.

+Documentation on livelihoods - economics, seasonal crops within the study area: This is the basis for calculating the demand for water in agriculture and environment to set the required flow of water for the rivers.

\subsection{Research Methods}

On the basis of the requirements, the authors used a combination of research methods including:

+) Statistical and analytical methods: Statistics for related research papers; Analysis of water level, flow at the stations in the Red River (Son Tay hydrological station, Hanoi hydrological station), as well as at Cam Dinh water intake (upstreamof Day river), Luong Phu water intake (upstreamTich river), Lien Mac water intake (upstream of Nhue river) to evaluate the evolution of water sources.

+) Site survey method: The authors also conducted field surveys to accurately propose the gravity water supply system.

+) Method of mathematical modeling: HEC-RAS 4.1 model has been used to simulatewater flowon river systems in the study area when constructing the gravity flow water supply system and regulating structures. Through the calculation results, evaluate the actual efficiency of the proposed route.

\section{Results}

\subsection{Successfully buildroute works for a gravity based water supply}

After considering all the elements, the study has proposed the construction of the route as follows: The proposed route originates from Km 36+670 Tich River, transporting water directly from the Tich River into the Day River at the position of Km 2+00 Day River through the channel N2. Continuing to go about $4.5 \mathrm{~km}$ along the Day river, the route changes direction and crosses Huu Day dyke at Dai village - Phung town - Dan Phuong district. Extending to the Dam River, the route will take advantage of the Dam river bed as a channel bringing water to the Nhue River. Running along the Nhue River about $250 \mathrm{~m}$, the routechanges its directionand continue to go along the Cau Da canal in Co Nhue commune $\mathrm{Tu}$ Liem district and then through the irrigation canal system in Xuan Dinh commune to To Lich River. 


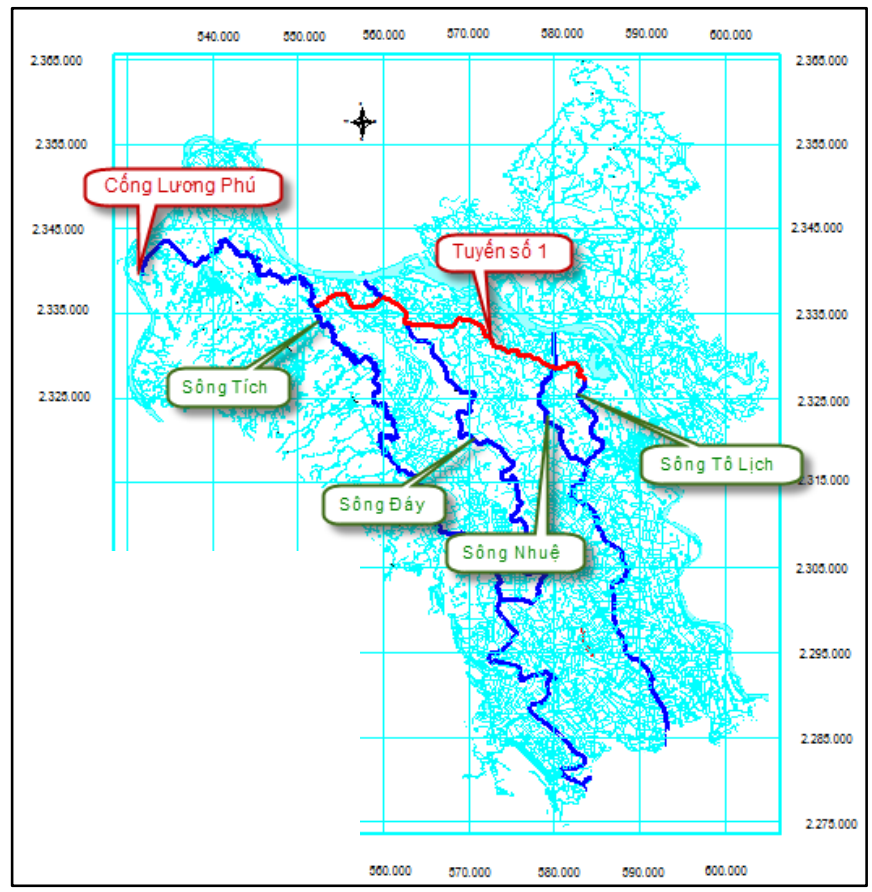

Fig. 5. Map of the proposedroute works for a gravity based water supply. The route has an average bed slope ofi $=\mathrm{H} / \mathrm{L} \cong 0,5 \cdot 10^{-4}$.

\subsection{Providing regulating structures on the route}

The four regulating structures on the four rivers (Tich River, Day River, Nhue River and To Lich River) and two combined weir-gates (one work located on the route connecting the Tich River and Day River, the last work situated on the route connecting Day River and Nhue River) are built to regulate water during the operation of the system.

Table 1. Summary table of works on the route.

\begin{tabular}{|c|c|c|c|}
\hline No. & Location & Proposed structures & Size \\
\hline 1 & Km 36+670 Tich River & Tich river regulating work & $\begin{array}{c}3 \text { compartments } \\
\mathrm{nx}(\mathrm{b} \times \mathrm{h})=3 \times(5 \times 3,5)(\mathrm{m})\end{array}$ \\
\hline 2 & $\begin{array}{l}\text { Upstream } 200 \mathrm{~m} \text { from } \\
\text { Intersection between the } \\
\text { Route and Day River. }\end{array}$ & Combined weir-gate No.1 & $\begin{array}{c}\text { Weir crest }+5,5 \\
\mathrm{nx}(\mathrm{b} \times \mathrm{h})=3 \times(5 \times 3)(\mathrm{m})\end{array}$ \\
\hline 3 & Km 06+800Day River & Day river regulating work & $\begin{array}{c}2 \text { water getting compartments: } \\
\text { bxh }=6 \times 5(\mathrm{~m}), \\
\text { 1waterway compartment: } \\
\text { bxh }=8 \times 8(\mathrm{~m})\end{array}$ \\
\hline 4 & $\begin{array}{l}\text { Upstream } 200 \mathrm{~m} \text { from } \\
\text { Intersection between the } \\
\text { Route and Nhue River. }\end{array}$ & Combined weir-gate No.2 & $\begin{array}{c}\text { Weir crest }+3,2 \\
\mathrm{nx}(\mathrm{b} \times \mathrm{h})=3 \mathrm{x}(5 \times 3)(\mathrm{m})\end{array}$ \\
\hline 5 & Km 04+360Nhue River & Nhue river regulating work & $\begin{array}{c}3 \text { compartments } \\
\mathrm{n}(\mathrm{b} \times \mathrm{x})=3 \times(3 \times 3,5)(\mathrm{m})\end{array}$ \\
\hline 6 & Upstream To Lich River & To Lich river regulating work & $\begin{array}{c}3 \text { compartments } \\
\mathrm{nx}(\mathrm{bxh})=3 \mathrm{x}(5 \times 3)(\mathrm{m})\end{array}$ \\
\hline
\end{tabular}




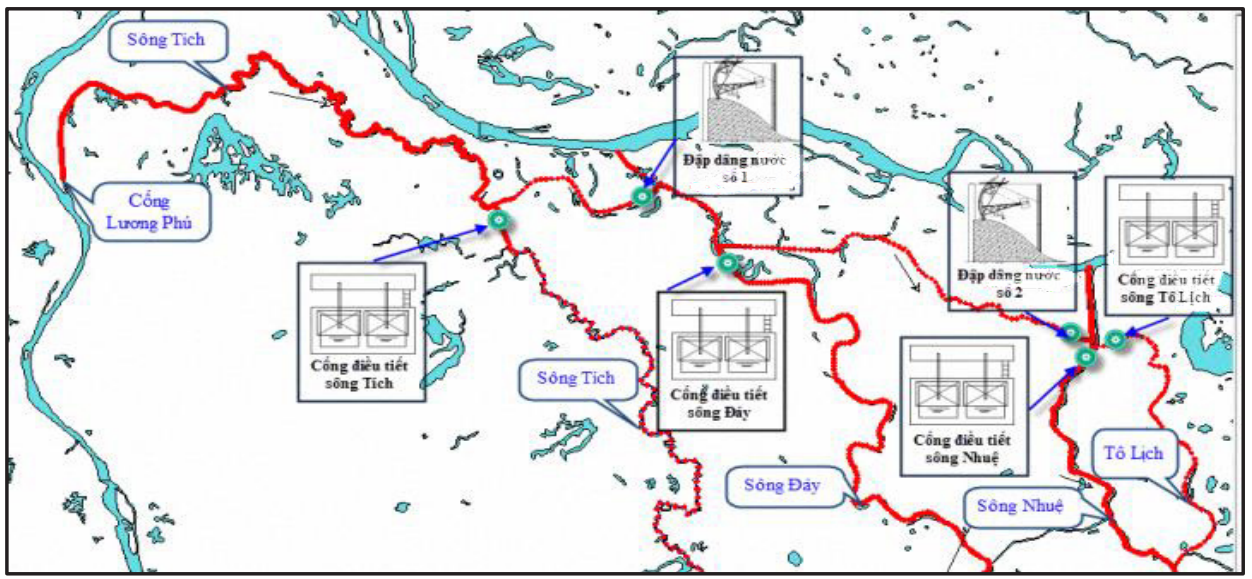

Fig. 6. Location of regulating works on the system.

\subsection{Evaluating the capability of thegravity flow water supply system on tranporting and regulating water by using HEC-RAS 4.1 model}

The research team has simulated the entire river system within the research area. Carrying out calibration and validation of the model to ensure that the model is set up to be the best fit. Allregulating works are also placed in the model (Fig. 6) to perform simulation calculations under defined scenarios.

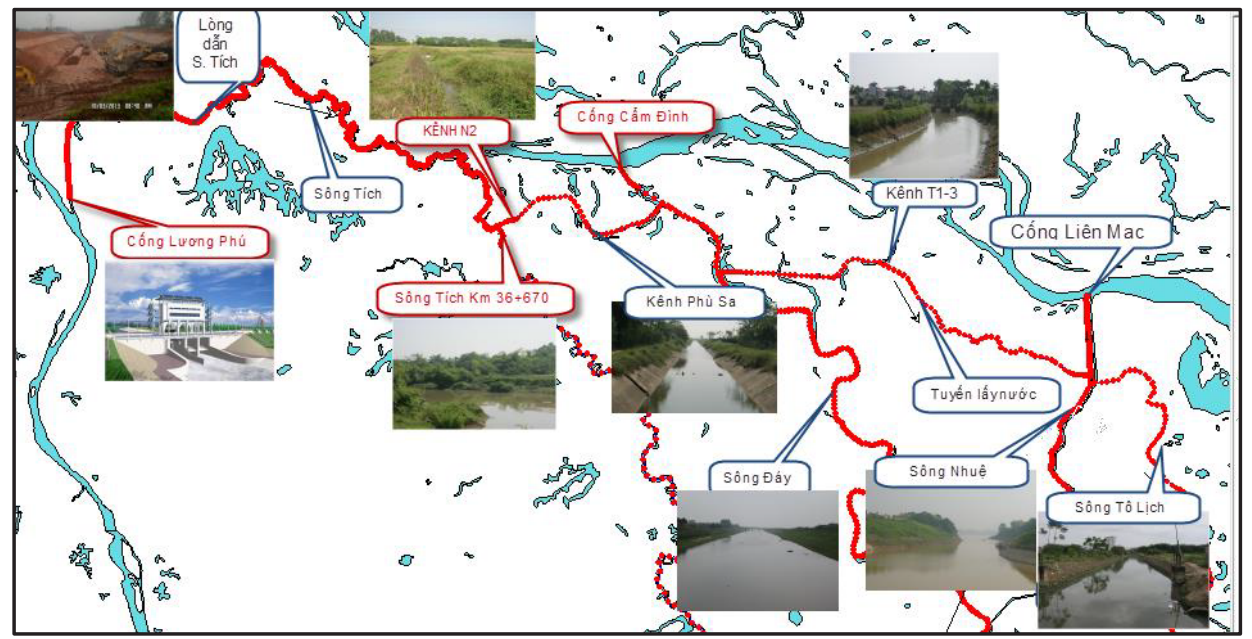

Fig. 7. The gravity flow water supply system is modeled.

\subsubsection{Calculating Scenario}

The scenario was chosen in which related factors are positive:

+ ) The water level at Luong Phu culvert on Da river is stable at: $+8.41 \mathrm{~m}$.

+ ) The water level at Lien Mac culvert on Nhue river is stable at: $+3.4 \mathrm{~m}$.

+ ) The water level at Cam Dinh culvert on Day river is stable at: $+5,35 \mathrm{~m}$. 


\subsubsection{Hydraulic Calculation Results}

Table 2. Water regulation based on the Scenario.

\begin{tabular}{|c|c|c|c|c|c|c|}
\hline \multirow[b]{2}{*}{ No. } & \multirow[b]{2}{*}{$\begin{array}{l}\text { Sub- } \\
\text { River }\end{array}$} & \multirow[b]{2}{*}{ Objectives } & \multicolumn{4}{|c|}{ Check points } \\
\hline & & & Location & $\begin{array}{l}\mathrm{H}(\mathrm{m}) \text { or } \\
\mathrm{Q}\left(\mathrm{m}^{3} / \mathrm{s}\right) \\
\text { needed }\end{array}$ & $\begin{array}{c}\mathrm{H}(\mathrm{m}) \text { or } \\
\mathrm{Q}\left(\mathrm{m}^{3} / \mathrm{s}\right) \\
\text { supplied }\end{array}$ & $\begin{array}{c}\text { Evaluation of } \\
\text { water supply } \\
\text { ability }\end{array}$ \\
\hline 1 & Tích & $\mathrm{H}, \mathrm{Q}$ designed & Ái Mỗ Bridge & $+5,14 \mathrm{~m}$ & $+5,17 \mathrm{~m}$ & $\mathrm{OK}$ \\
\hline 2 & Đáy & H,Q designed & $\begin{array}{c}\text { Hiệp Thuận } \\
\text { Culvert }\end{array}$ & $+4,28 \mathrm{~m}$ & $+4,28 \mathrm{~m}$ & OK \\
\hline 3 & Nhuệ & H,Q designed & $\begin{array}{c}\text { Hà Đông } \\
\text { Culvert }\end{array}$ & $+2,85 \mathrm{~m}$ & $+2,82 \mathrm{~m}$ & OK \\
\hline 4 & Tô Lịch & $\begin{array}{l}\text { eliminate polution, maintain } \\
\text { environmental flows. }\end{array}$ & Along the river & $30 \mathrm{~m}^{3} / \mathrm{s}$ & $29,29 \mathrm{~m}^{3} / \mathrm{s}$ & OK \\
\hline
\end{tabular}

According to the scenario, in positive condition in which water levels in rivers are stable, the headworks like Cam Dinh, Lien Mac 1 can work properly following the design criterias, the flow in the rivers can not only ensure the discharge which could heal the To Lich river $(\approx 30$ $\mathrm{m} 3 / \mathrm{s}$ ) but also ensure the operational condition of irrigation systems along the main rivers.

\section{Discussion}

\subsection{Route Works for a gravity based water supply system}

Researching and deciding a optimum alternative for a gravity based water supply system have to ensure not only to supply a certain amount of water for the rivers but also some other factors below:

+ Social Factors: the route works fora gravity based water supply system can violate a big amount of space. Therefore, in the process of making plans, the optimum alternative should avoid overlaying high concentrated population, which could result in changes in habits and traditions of local people. this route works should also go along the boder of these areas in order to suplement a significant amount of water for groundwater, making space and advantages for social- economic development for these areas.

+ Economic Factors: the costs for clearance and construction have to be minimized. in order to do this, beside applying high technologies, we need to think about the uses of existing works to be a part of the route works.

+ The Safety of works and Humans: this area has a stable condition of Geology. In the process of operation, the works have to be protected away from natural hazards such as storms, floods... Mitigate and avoid flooding in Ha Noi center.

With the slope of river bed $\mathrm{i}=\mathrm{H} / \mathrm{L} \cong 0,5.10-4$, the ability of leading water from Tich river along the route works to Day river, and Nhue river is relatively feasible and able to apply in the reality.

\subsection{Proposals of Regulating works along the route}

The regulating works would be considered to be situated at the intersections of the route with Day, Nhue, To Lich River and existing works. at these locations, the research group has taken consideration on morphology, geology, discharge in order to design regulating culverts and weirs. By the method of running hydraulic model on this scenario, the research group have figured out the locations, number of regulating works which are proper and optimum.

\subsection{Water quality of To Lich river following the scenario}


Based on applying the module of Water Quality Analysis of HEC-RAS 4.1, with the data of existing water quality of To Lich river collected by Ha Noi Water Supply JSC (2012), water quality is stimulated by the research group after having new sourse of water. Results are presented below:

- after being supplied with a discharge $\mathrm{Q}=30 \mathrm{~m} 3 / \mathrm{s}$ in order to rehabilitate natural flow, water quality along To Lich river would change in positive way, especially the amount of DO.

- Concentration of BOD along the To Lich river from upstream to downstream is disolved by the flow, the process of changing concentration of disovled organic. the concentration of BOD decreases significantly but still above the B2 level, which is regulated in "National standard of water surface quality QCVN 08:2008/BTNMT". the lowest value of BOD $=11$ $\mathrm{mg} / \mathrm{l}$ at the entrance of Tô Lịch river, the highest is $72 \mathrm{mg} / \mathrm{l}$ at the intersection of Lừ and Tô Lịch river.

- The concentration of DO along the To Lich river has been supplemented and improved significantly. After being supplied, it increases significantly, the lowest concentration of DO $=3,3 \mathrm{mg} / \mathrm{l}$ is at the intersection of Lu and To Lich river, and the highest is $5,3 \mathrm{mg} / \mathrm{l}$ at the upstream of the river. they are above B2.

- According to the standard of national water quality TCVN 6773:2000 - it was clearly stated that the water for agricultural irrigation should have the concentration of DO $\geq 2 \mathrm{mg} / \mathrm{l}$.

\section{Conclusions}

In this study, the research group proposed a solution for supplying water at dead rivers in Ha Noi Center which is the route works of gravity based water suplly cooporating with existing works on the route, leading water from Tich river to Day, Nhue and To Lich rivers. In good conditions, To Lich river could have a discharge of $Q=30 \mathrm{~m} 3 / \mathrm{s}$.

By using 1-dimentional model HEC-RAS V4.1, we use the results to evaluate the efficiency of the solution of the route works. From the results, this solution is evaluated feasibly and efficiently. By analysing and evaluating the ability of leading and supplying water of the route works, we can say that: it is feasible to bring this solution to the real life, which not only helps to rehabilitate the To Lich river as it is used to be but also ensures the ability of operation of irrigation system on the main rivers (Tich, Day and Nhue rivers)

\section{Acknowledgement}

Thanks to our collegues at Thuyloi University and The Institute of Civil Enginerring who shared their documents and comments to our research, which contributed to a significant part of our sucess.

\section{References}

1. Hydrologic analysis-, Creating water flow for and upgrading Tich River (2011)

2. N. Canh Cam, Hydraulic open flow (Construction Publishing House, 2006)

3. Thuyloi University, Hydrology and Environment HEC-RAS, (2009)

4. HEC - RAS v4.1, Applications Guide (2010)

5. HEC - RAS v4.1, Users Manual (2010) 